\title{
Penjatuhan Sanksi Pidana Kepada Anak yang Membawa Prekursor Narkotika
}

\author{
Nopiyan \\ Fakultas Hukum, Universitas Muhammadiyah Yogyakarta \\ Email : nopiyan.umy@gmail.com
}

\section{Info Artike}

\section{Kata Kunci :}

Anak,

Prekursor Narkotika,

Sanksi Pidana

\section{Perjalanan Artikel :}

Diterima : 25 Januari 2020

Direview : 01 Februari 2020

Direvisi : 13 Maret 2020

Dipublikasikan : Maret 2020

DOI: 10.18196/ijclc.v1i1.9128

\begin{abstract}
Abstrak
Tingginya nilai sebuah peradaban menimbulkan kemajuan bagi kehidupan manusia namun juga membawa dampak buruk jika semua itu tidak ditempatkan pada tempatnya, terutama terhadap anak-anak. Anak sebagai tunas dan penerus bangsa seharusnya dijaga dan dilindungi hak dan kewajibannya untuk tidak melakukan hal yang tidak sesuai dengan usia dan lingkungannya serta memperhatikan pergaulan anak saat ini sangat berbahaya disaat bergaul secara bebas biasa berdampak pada penyalahgunaan narkotika seperti dalam kasus ini dimana desakan dari teman yang mengarah kepada anak-anak untuk melakukan tindak pidana narkotika. Metode penelitian yang digunakan adalah penelitian hukum normatif yang dilakukan dengan studi kepustakaan untuk mendapatkan informasi serta data yang terkait mengenai aturan hukum yang ada guna menjawab isu hukum yang berkembang dan dihadapi. Hasil dari penelitian menunjukkan bahwa terdapat faktor desakan dari teman yang membuat tindak pidana pemufakatan jahat membawa prekursor narkotika tersebut terjadi dan hakim dalam memutus perkara tersebut dalam pertimbangannya telah sesuai dengan ketentuan perundang-undangan yang berlaku sebagaimana terdapat dalam ketentuan Undang-Undang Nomor 35 Tahun 2009 tentang Narkotika, KUHP dan Undang-Undang Pengadilan Anak. Tindak pidana pemufakatan jahat membawa prekursor narkotika yang terjadi diwilayah hukum Pengadilan Negeri Sleman yang dilakukan oleh anak-anak terselesaikan melalui persidangan dengan Perkara Nomor : 218/Pid.Sus/2013/Pn.Slmn dimana terdakwa dipidana dengan pidana penjara 1 (satu) tahun 6 (enam) bulan
\end{abstract}

\section{Pendahuluan}

Semakin tingginya nilai sebuah peradaban dari masa ke masa tentunya mampu memberikan kemajuan bagi kehidupan manusia, namun tidak dapat dilupakan juga bahwa di sisi lain dari kemajuan yang ditimbulkan akan membawa dampak yang buruk terhadap manusia jika semuanya itu tidak ditempatkan pada tempatnya. ${ }^{1}$

Tindak pidana dapat terjadi pada siapapun dan dapat dilakukan oleh siapapun baik pria, wanita, maupun anak. Apabila ada tindak pidana yang melibatkan anak, tentu anak tersebut perlu mendapatkan perlakuan serta perlindungan yang khusus karena anak yang melakukan tindak pidana adalah anak yang belum matang fisik maupun mentalnya sehingga masih perlu bimbingan

1 Ngawiardi, "Kajian Kriminologi Terhadap Kejahatan Pencabulan Anak Di bawah Umur di Parigi Moutong", https://www.neliti.com/id/universitas-tadulako?per_page=50\&page=10, diakses Selasa 7 Mei 2019, 
agar kelak dapat menjadi orang yang lebih baik. Penerapan sanksi pidana bagi mereka yang melakukan kejahatan tidak hanya didapatkan bagi mereka yang usianya dewasa, tetapi pemidanaan bagi anak juga telah lama diterapkan. Secara sosiologis perkembangan anak yang melatar belakangi seorang anak untuk melakukan tindak pidana sebagaimana yang telah ada dalam hukum positif, perbuatan yang dikualifikasikan sebagai tindak pidana anak adalah setiap perbuatan baik berupa kejahatan maupun pelanggaran sebagaimana diatur dalam peraturan perundang-undangan hukum pidana. bahkan berdasarkan Undang-Undang Nomor 3 Tahun 1997 tentang Pengadilan Anak diperluas lagi, bukan hanya perbuatan yang dilarang oleh perundang-undangan hukum pidana, melainkan termasuk perbuatan-perbuatan yang dilarang menurut peraturan hukum lain yang hidup dan berlaku dalam masyarakat. ${ }^{2}$

Anak adalah bagian dari generasi muda sebagai salah satu sumber daya manusia yang merupakan potensi dan penerus cita-cita perjuangan bangsa, memiliki peranan strategis dan mempunyai ciri dan sifat khusus, memerlukan pembinaan dan perlindungan dalam rangka menjamin pertumbuhan dan perkembangan fisik, mental, dan sosial secara utuh, serasi, selaras, dan seimbang. ${ }^{3}$ Hal tersebut didasari karena anak memiliki keterbatasan dalam melindungi diri mereka sendiri dari berbagai pengaruh. 4

Pengertian anak menurut Pasal 1 angka 1 Undang-Undang Nomor 35 Tahun 2014 tentang Perubahan Atas Undang-Undang Nomor 23 Tahun 2002 tentang Perlindungan Anak menyebutkan bahwa "anak adalah seseorang yang belum berusia 18 (delapan belas) tahun, termasuk anak yang masih dalam kandungan". Oleh karena itu, setiap anak memerlukan perlindungan dari berbagai kejahatan yang dapat mengancam anak tersebut. Pengaturan hukum pidana terhadap berbagai bentuk kejahatan terhadap anak-anak tercantum dalam Undang-Undang Nomor 35 Tahun 2014 tentang Perlindungan Anak. Sebagaimana yang tertulis pada bagian "menimbang", salah satu konsiderans pembentukan Undang-Undang Nomor 23 Tahun 2002 adalah :

"bahwa setiap anak perlu mendapat kesempatan yang seluas-luasnya untuk tumbuh dan berkembang secara optimal, baik fisik, mental maupun sosial, dan berakhlak mulia, perlu dilakukan upaya perlindungan serta untuk mewujudkan kesejahteraan anak dengan memberikan jaminan terhadap pemenuhan hak-haknya serta adanya perlakuan tanpa diskriminatisi". ${ }^{5}$

Meningkatnya penyalahgunaan Narkotika dewasa ini sangat erat kaitannya dengan penggunaan alat-alat yang berpotensi dalam penyalahgunaan Narkotika maupun prekursor sebagai salah satu zat atau bahan pemula atau bahan kimia yang digunakan untuk memproduksi Narkotika secara gelap. Penyalahgunaan prekursor dalam pembuatan Narkotika dan Psikotropika telah menjadi ancaman yang sangat serius yang dapat menimbulkan gangguan bagi kesehatan, instabilitas ekonomi, gangguan keamanan, serta kejahatan internasional oleh karena itu perlu diawasi secara ketat agar dapat digunakan sesuai peruntukannya. ${ }^{6}$ Pengendalian dan pengawasan sebagai upaya pencegahan dan memberantas penyalahgunaan dan peredaran gelap prekursor sangat membutuhkan langkahlangkah konkrit, terpadu dan terkoordinasi secara nasional, regional maupun internasional, karena kejahatan penyalahgunaan prekursor pada umumnya tidak dilakukan oleh perorangan secara sendiri melainkan dilakukan secara bersama-sama, bahkan oleh sindikat yang terorganisasi rapi dan sangat rahasia. $^{7}$

2 Nandang Sambas, Pembaruan Sistem Pemidanan Anak di Indonesia, Yogyakarta, Graha Ilmu, 2010, hlm. 208

3 Titik Hastary, Skripsi: Perlindungan Hukum Terhadap Anak Yang Melakukan Tindak Pidana (Studi Di Pengadilan Negeri Sukoharjo), Surakarta, Fakultas Hukum, Universitas Muhammadiyah Surakarta, 2013, hlm. 1

4 Muhammad Taufik Makarao dkk, Hukum Perlindungan Anak dan Perempuan dalam Kekerasan Rumah Tangga, Jakarta, Rineka Cipta, 2013, hlm. 1

5 Aziz Syamsuddin, Tindak Pidana Khusus, Jakarta, Sinar Grafika, 2014, hlm. 106-107

6 Ayu A. A Hamzah, Pemidanaan Terhadap Penyalahgunaan Prekursor Di Kalangan Korporasi, Jurnal Lex Crimen, 2014, Vol. 3 No. 2, hlm. 5

7 Ibid. 


\section{Rumusan Masalah}

1. Mengapa terhadap pelaku oleh majelis hakim disebutkan melakukan pemufakatan jahat membawa prekursor narkotika?

2. Bagaimana penjatuhan sanksi terhadap terdakwa dalam perkara pemufakatan jahat membawa prekursor?

\section{Metode Penelitian}

Dalam penelitian ini menggunakan bahan hukum yaitu :

1. Bahan Hukum Primer

Bahan primer adalah bahan hukum yang sifatnya otoritatif yang berarti mempunyai otoritas. Bahan-bahan hukum primer terdiri dari :
a. Undang-Undang Nomor 1 Tahun 1946 tentang Peraturan Hukum Pidana (KUHP).
b. Undang-Undang Nomor 8 Tahun 1981 tentang Hukum Acara Pidana (KUHAP).
c. Undang-Undang Nomor 35 Tahun 2009 tentang Narkotika.
d. Undang-Undang Nomor 11 Tahun 2012 tentang Sistem Peradilan Pidana Anak.
e. Putusan Hakim Pengadilan Negeri Sleman Nomor : 218/Pid.Sus/2013/Pn.Slmn

2. Bahan Hukum Sekunder

Bahan Hukum Sekunder yaitu bahan hukum yang dapat memberikan penjelasan berupa semua publikasi tentang hukum yang bukan merupakan dokumen-dokumen resmi untuk membantu proses analisis yang berisi prinsip-prinsip dasar ilmu hukum dan pandangan-pandangan klasik para sarjana yang mempunyai kualifikasi tinggi, yakni sebagai berikut:

a. Buku-buku teks terutama tentang narkotika dan anak.

b. Jurnal-jurnal hukum antara lain yaitu Lex Crimen, Diponegoro Law Journal.

c. Hasil penelitian ilmiah antara lain yaitu skripsi Dasar Pertimbangan Hakim Dalam Menentukan Sanksi Pidana Bagi Residivis Narkotika oleh Himawan Setiaji

d. Surat kabar serta Berita internet. ${ }^{8}$

3. Bahan Hukum Tersier

Bahan Hukum Tersier yaitu bahan hukum yang dapat menjelaskan baik bahan hukum primer maupun bahan hukum sekunder, seperti

a. Kamus Besar Bahasa Indonesia Antara lain yaitu arti residive

b. Ensiklopedi

c. Leksikon dan lain-lain. ${ }^{9}$

4. Narasumber

Narasumber adalah orang yang memberikan pendapat atas objek yang diteliti oleh peneliti. Hubungan narasumber dengan objek yang diteliti disebabkan kompetensi keilmuan yang dimiliki oleh narasumber.yang menjadi narasumber dalam penelitian ini adalah :

a. Suparna S.H. selaku Hakim di Pengadilan Negeri Slman. ${ }^{10}$

Bahan hukum dari hasil penelitian yang dilakukan oleh penulis dapat dianalisa atas informasi yang diperoleh dari bahan hukum dan menghubungkannya dengan bahan hukum primer, bahan hukum sekunder dan bahan hukum tersier. Kesimpulan yang dituangkan dalam Analisis bahan hukum akan dilakukan setelah diperoleh dari bahan hukum primer, sekunder dan tersier sehingga dapat memberikan sebuah jawaban yang jelas atas

8 Peter mahmud marzuki, Penelitian hukum, Jakarta, Kencana Prenada Media Group, 2013, hlm.181

9 Mukti Fajar \& Yulianto Achmad, Dualisme Penelitian Hukum Normatif \& Empiris, Yogyakarta, Pustaka Pelajar, 2015, hlm.158

$10 \quad$ Ibid, hlm. 175 
permasalahan yang diangkat dan tujuan penelitian yang menggunakan asas-asas hukum, doktrin, dan pendapat para ahli yang di rangkai secara sistematis. ${ }^{11}$

\section{Hasil Penelitian dan Analisis}

\section{Terdakwa di Nyatakan Melakukan Pemufakatan Jahat Membawa Prekursor Narkotika}

Putusan Perkara Nomor : 218/Pid.Sus/2013/Pn.Slmn yang menjatuhkan pidana terhadap perkara Pemufakatan Jahat Membawa Prekursor Narkotika Golongan I terdakwa dianggap memenuhi unsur Pasal 132 ayat (1) yang berbunyi "Percobaan atau permufakatan jahat untuk melakukan tindak pidana narkotika dan prekursor narkotika sebagaimana dimaksud dalam Pasal 111, 112, 113, 114, 115, 116, 117, 118, 119, 120, 121, 122, 123, 124, 125, 126 dan Pasal 129 pelakunya dipidana dengan pidana yang sama sesuai dengan ketentuan sebagaimana dimaksud dalam Pasal-Pasal tersebut".

Hakim berpendapat dalam pertimbangannya bahwa : berdasarkan penjelasan dari ketentuan Pasal 132 ayat (1) Undang-Undang Nomor 35 Tahun 2009 tentang Narkotika yang dimaksud dengan percobaan adalah adanya unsur niat, adanya permulaan pelaksanaan dan tidak selesainya pelaksanaan bukan semata-mata disebabkan karena kehendak sendiri, kemudian berdasarkan ketentuan Pasal 1 angka 18 Undang-Undang Nomor 35 Tahun 2009 tentang Narkotika yang dimaksud dengan permufakatan jahat adalah perbuatan dua orang atau lebih yang bersekongkol atau bersepakat untuk melakukan, melaksanakan, membantu, turut serta melakukan, menyuruh, menganjurkan, memfasilitasi, memberi konsultasi, menjadi anggota suatu organisasi kejahatan narkotika, atau mengorganisasikan suatu tindak pidana narkotika. Sebagaimana pertimbangan hakim adalah :

Menimbang, bahwa berdasarkan keterangan saksi AD, Saksi HH, Saksi WP,SH, Saksi BA , Saksi I dan keterangan Terdakwa serta fakta yang terungkap dipersidangan bahwa pada hari Jum'at tanggal 19 April 2013 sekitar jam 08.00 wib terdakwa dijemput oleh Saksi BA di rumah terdakwa di daerah Gendeng, lalu terdakwa diajak oleh Saksi BA untuk main ke rumah temannya di daerah Nologaten, dalam perjalanan terdakwa di hubungi oleh Tanto melalui SMS yang intinya ingin bertemu dengan terdakwa. selanjutnya ketika di rumah temannya Saksi BA, sekira jam 10.15 wib Tanto datang menyusul terdakwa, lalu terdakwa keluar menemui Tanto, dimana saat itu Tanto meminta pada terdakwa untuk memesan ganja pada Kodok, Kemudian terdakwa menguhubungi Kodok melalui SMS untuk memesan ganja, lalu ketika itu juga Kodok mengirimkan SMS lagi pada terdakwa yang memberitahu mengenai harga ganja pesanannya tersebut, kemudian SMS dari Kodok itu Terdakwa tunjukkan pada Tanto, selanjutnya Tanto langsung pamit pergi ke ATM Bank. Bahwa benar kemudian terdakwa mengirim SMS lagi pada Kodok meminta nomer rekening milik Kodok, setelah itu nomer rekening milik Kodok, terdakwa kirim lagi melalui SMS kepada Tanto, yang selanjutnya terdakwa mendapat SMS dari Kodok yang menginformasikan mengenai petunjuk tempat untuk mengambil pesanan ganjanya yang mana isi SMS dimaksud yaitu " $1 \mathrm{G}$ di Wirobrajan ada pertigaan belok kanan, disebelah kanan jalan ada pintu besi besar, disitu ada 2 tiang besar, utara pintu besi barang ada disitu ditaruh dibungkus plastik kresek warna hitam ", kemudian terdakwa memperlihatkan isi SMS dari Kodok dimaksud pada Saksi BA, lalu terdakwa mengajak Saksi BA untuk menemani dan mengantarkan terdakwa mengambil ganja dimaksud di daerah Wirobrajan karena terdakwa tidak mengetahui tempat alamat yang dimaksud, kemudian terdakwa bersama dengan Saksi BA pergi dengan menggunakan sepeda motor untuk mengambil ganja sesuai dengan petunjuk alamat dimaksud dan sekitar jam 20.30 wib terdakwa dan Saksi BA tiba di alamat tempat ganja tersebut berada, lalu Saksi BA turun dari sepeda motor dan membaca lagi SMS petunjuk keberadaan ganja dimaksud yang ada di HP milik terdakwa, setelah itu Saksi BA langsung mencari di semak-semak yang akhirnya Saksi BA menemukan 1 (satu) bungkus plastik kresek warna hitam yang berisi ganja yang dibungkus dengan kertas koran, kemudian Saksi BA (Terdakwa dalam Perkara Terpisah) mengambil dan menyimpan 1 bungkus plastik kresek

11 Ibid, hlm.183 
warna hitam yang berisi ganja dimaksud di dalam bajunya. ${ }^{12}$ Menimbang, berdasarkan keterangan terdakwa dan fakta yang terungkap dipersidangan bahwa setelah mendapatkan ganja tersebut terdakwa dan Saksi BA (Terdakwa dalam Perkara Terpisah) pergi lagi namun ditengah perjalanan berhenti, lalu terdakwa menanyakan dan mengambil 1 bungkus plastik kresek warna hitam yang berisi ganja dimaksud dari dalam baju Saksi BA (Terdakwa dalam Perkara Terpisah), selanjutnya terdakwa menyimpan 1 bungkus plastik kresek warna hitam yang berisi ganja tersebut di dalam tas warna coklat milik terdakwa, selanjutnya terdakwa dan Saksi BA pergi lagi menuju ke tempat kerja Saksi I di Cafe Lagend, dimana saat itu terdakwa menunggu diluar dan Saksi BA mengajak Saksi I untuk menghisap ganja, yang selanjutnya terdakwa bersama-sama dengan Saksi BA dan Saksi I pergi lagi menuju ke sebuah warung kosong dengan mengunakan sepeda motor di dekat rumah Saksi I di daerah Tukangan Kota Yogyakarta dan setelah sampai di warung kosong tersebut, kemudian terdakwa, Saksi BA dan Saksi I melinting ganja sebanyak 3 linting dan menghisapnya tetapi terdakwa menghisap ganja tersebut belum sampai habis karena sekira jam 22.30 wib terdakwa mendapat SMS dari Tanto yang menayakan tentang ganja tersebut, lalu terdakwa pergi untuk menemui Tanto yang katanya sudah menunggu di atas jembatan Kewek dengan maksud terdakwa akan menyerahkan ganja pesanan Tanto dimaksud. Selanjutnya ketika terdakwa sampai di atas jembatan Kewek di daerah Kotabaru Yogyakarta tersebut, dan ketika itu datang petugas Kepolisian yang berpakaian preman mendekati terdakwa dan melakukan penggeledahan lalu ditemukan ganja yang dibungkus kertas warna putih di dalam dompet warna hitam serta daun ganja yang dibungkus dengan kertas koran dalam plastik kresek warna hitam yang semuanya berada di dalam tas warna coklat milik terdakwa, kemudian terdakwa ditangkap berserta barang buktinya, yang selanjutnya pada malam itu juga Saksi BA dan Saksi I ditangkap pula oleh Polisi di masing-masing tempat terpisah. ${ }^{13}$ Menimbang, berdasarkan pertimbanganpertimbangan tersebut diatas, maka Hakim berpendapat bahwa unsur "Percobaan atau Permufakatan Jahat Untuk Melakukan Tindak Pidana Narkotika dan Prekursor Narkotika" telah terpenuhi, akan tetapi secara tegas Hakim tidak menyebutkan tindakan atau perbuatan yang mana yang memenuhi unsur dari permufakatan jahat.

Berbeda halnya dengan putusan Perkara Nomor : 152/Pid.Sus/2018/Pn.Rhl dimana hakim dalam pertimbangannya menyebutkan bahwa :

Menimbang, bahwa unsur ini bersifat alternatif, dimana berarti bila salah satu perbuatan atau lebih sebagaimana dimaksud diatas telah terpenuhi atas perbuatan terdakwa maka unsur ini dapat terbukti ; Menimbang, Bahwa sebagaimana fakta persidangan, berdasarkan keterangan para saksi yang dihubungkan dengan keterangan terdakwa yang membenarkan keterangan para saksi tersebut serta barang bukti dan surat, telah diperoleh fakta hukum pada hari Kamis tanggal 25 Januari 2018 sekira pukul 18.00 WIB, saksi Andri Roy bersama saksi Firmansyah mendapat informasi dari Masyarakat terpercaya bahwa di sebuah ruko bertuliskan Tomi Service Jalan Lintas Riau-Sumut KM.5 Desa Balai Jaya Kecamatan bagan Sinembah Kabupaten Rokan Hilir akan ada transaksi jual beli Narkotika jenis sabu-sabu, kemudian para saksi penangkap langsung melakukan penyelidikan dilapangan dan sekira pukul $18.00 \mathrm{Wib}$ para saksi melihat Saksi Hendra masuk ke dalam ruko tersebut, lalu melihat Terdakwa Henny Purwati dan Terdakwa Riswanto diduga sedang melakukan transaksi Narkotika dengan Saksi Hendra, kemudian para saksi penangkap langsung melakukan penggeledahan dan ditemukan barang bukti berupa 1 (satu) paket kecil Narkotika jenis sabu-sabu, 29 (dua puluh sembilan) lembar plastik bening pembungkus Narkotika jenis sabu-sabu, 1 (satu) buah timbangan digital, 1 (satu) buah kaca pirex, 1 (satu) buah bong penghisap sabu, 1 (satu) buah Handphone merk Samsung, 1 (satu) buah Handphone merk Strawberry, 1 (satu) buah Handphone tablet merk Advan, dan Uang Sejumlah Rp.550.000,00 (lima ratus lima puluh ribu rupiah); Menimbang, Bahwa sekira pukul 11.30 Wib Terdakwa Henny Purwati dan Terdakwa Riswanto memesan Narkotika jenis sabu-sabu seberat $1 / 2$ gram seharga Rp.550.000,00 (lima ratus lima puluh ribu rupiah) kepada Saksi Hendra melalui Terdakwa I Henny Purwati mengatakan akan menjemput

12 https://putusan.mahkamahagung.go.id/putusan/46d1bd9588c2a6cb2cb99f2d9e0821c9, Putusan Nomor : 218/Pid.sus/2013/Pn.Slmn, diakses pada 6 November 2018, 11:00 wib, hlm.23

13 Ibid, hlm 24 
Narkotika tersebut di Ruko yang bertuliskan Tomi Servis Jalan Lintas Riau-Sumut Km.5 Desa Balai Jaya KecamatanBagan Sinembah Kabupaten Rokan Hilir; Menimbang, bahwa dengan telah terjadinya tindak pidana penyalahgunaan narkotika jenis sabu tersebut Majelis Hakim berkesimpulan terdakwa adalah orang yang telah menawarkan untuk dijual Narkotika golongan I bukan tanaman, dimana dalam melakukan perbuatannya tersebut Terdakwa terbukti adanya permufakatan jahat antara Terdakwa dan Saksi Henny Purwati dan Riswanto, sehingga unsur ke-3 ini telah pula terpenuhi; ${ }^{14}$

Dalam perkara diatas secara jelas hakim menyebutkan bahwa terdakwa dan saksi Henny Purwati serta Riswanto terbukti adanya melakukan permufakatan jahat.

a. Tindak Pidana Narkotika

Tindak Pidana Narkotika, adalah serangkaian perbuatan terlarang oleh UndangUndang Narkotika, dan tercela dalam kaitan dengan kegiatan pemakaian dan peredaran atau perdagangan penggunaan obat atau zat kimia yang berfungsi menurunkan tingkat kesadaran ingatan atau fisik bahkan menimbulkan masalah dan gangguan kesehatan kejiwaan seseorang dalam situasi dan kondisi tertentu yang telah terjadi, karenanya dapat dikenakan sanksi fisik maupun moral bahkan perampasan kekayaan bagi pelakunya. ${ }^{15}$ Selanjutnya jenis tindak pidana narkotika terdiri dari tindak pidana narkotika golongan I,Jenis Narkotika yang secara umum dikenal masyarakat antara lain Ganja, Sabu-sabu, Kokain,Opium, Heroin, dll; tindak pidana narkotika golongan II, Jenis Narkotika yang secara umum dikenal masyarakat antara lain Morfin, Pertidin dll; dan tindak pidana narkotika golongan III, Jenis Narkotika yang secara umum dikenal masyarakat antara lain Kodein, dll. ${ }^{16}$

b. Faktor Anak Menjadi Pelaku Tindak Pidana Narkotika

Putusan Perkara Nomor : 218/Pid.Sus/2013/Pn.Slmn menyebutkan sebagaimana terdapat dalam laporan dari pembimbing kemasyarakan dengan No.Daf : A2/59/Lit.PN/A/IV/13 atas nama DN menjelaskan bahwa DN sejak kelas IV SD ayahnya sudah meninggal dunia yang kemudian diasuh oleh ibunya seorang diri (single parent) yang bersikap memanjakan namun kurang bias maksimal dalam mendidik anak dan DN lebih banyak bergaul dengan lawan jenis yang lebih dewasa serta mempunyai hobi berfoya-foya minum-minuman keras dan mengonsumsi obat terlarang, sebagimana penjelasan dalam putusan diatas maka dapat dikatakan bahwa DN menjadi pelaku tindak pidana berdasarkan lingkungannya.

c. Teori Kenakalan Anak

Friedlander dan Apte menjelaskan bahwa kenakalan tidak disebabkan oleh satu sumber, antara lain faktor heredeter, struktur biologis, atau pengaruh lingkungan, tetapi oleh beranekaragam faktor yang saling berkaitan. ${ }^{17}$ Faktor-faktor tersebut antara lain heredeter dan biologis: kesehatan yang buruk, cacat fisik, ketidaknormalan, gangguan saraf, berbagai tingkatan gangguan mental termasuk psikosis, instabilitas mental, perasaan selalu tidak aman, dorongan seksual tidak terkontrol, atau perilaku neurotis. Faktor-faktor lingkungan: penelantaran atau penolakan oleh orangtua, anggota keluarga lain atau teman; pengaruh merusak keluarga pecah; sikap kriminal keluarga, tetangga atau kelompok penjahat di daerah kumuh; kemiskinan keluarga; perjudian; pergaulan buruk;

${ }^{14}$ https://putusan.mahkamahagung.go.id/putusan/cf17ede036c7f818b1cfd928c1b3a9a2, diakses Senin 1 Juli 2019, $21.00 \mathrm{Wib}$

15 Anton Sudanto, Penerapan Hukum Pidana Narkotika Di Indonesia, ADIL: Jurnal Hukum, 2017, Vol. 7 No.1, hlm. 139

16 https://jurnal.usu.ac.id/index.php/jmpk/article/view/1483/ diakses Senin 1 Juli 2019, 20.30 Wib

17 Ida Nor Shanty, Suyahmo dan Slamet Sumarto, Faktor Penyebab Kenakalan Remaja Pada Anak Keluarga Buruh Pabrik Rokok Djarum Di Kudus, Unnes Civic Education Journal, 2015, Vol.1 No. 2, hlm. 2 
pendidikan rendah; kurangnya rekreasi sehat; pengaruh merusak dari TV, radio, koran, cerita kriminal, bioskop dan buku komik. ${ }^{18}$

Sementara itu Muhidin melihat bahwa sebab-sebab dari kenakalan anak sangat kompleks. Sebab-sebab kenakalan anak-anak dapat dikategorikan menjadi tiga kelompok, yaitu faktor individu, faktor keluarga, dan faktor masyarakat. ${ }^{19}$ Faktor individu, Termasuk faktor individu adalah kondisi biologis, seperti cacat fisik, kelemahan biologis yang mengakibatkan pertumbuhan dan tingkah laku abnormal. Anak-anak yang mengalami kemunduran mental dan pertumbuhan intelegensi di bawah normal, psychopathic, dan neorosa yang memungkinkan anak-anak melakukan tindakan asosial. ${ }^{20}$ tingkah laku kenakalan termasuk ketidakstabilan emosi yang disebabkan oleh rasa rendah diri, temperamen yang tidak terkontrol dan konflik-konflik dalam diri. Sebab-sebab lain dari kenakalan yang termasuk faktor individu adalah kebiasaan pada waktu kecil yang selalu dalam keadaan ketakutan dan penyalahgunaan alkohol dan narkotika. Faktor keluarga. Pengaruh negatif dari kehidupan keluarga, seperti perceraian atau perpecahan rumah tangga, adalah anak-anak menjadi terlantar. Anak-anak tidak mendapatkan kasih sayang dan perawatan yang wajar. Keluarga yang selalu bertengkar, tanpa disiplin serta kondisi perumahan yang tidak memadai, kurangnya waktu luang dan rekreasi serta kurangnya pendidikan moral dan agama dalam keluarga, juga menyebabkan kenakalan. Faktor masyarakat. Pengaruh dari "gang" dan street corner association (kelompok anak jalanan) yang disebabkan oleh kurangnya rekreasi yang sehat dan community centre atau youth centres mendorong anak untuk berkumpul dan berkenalan dengan peminum, penjudi, dan prostitusi. ${ }^{21}$ Juga pengaruh negatif dari film, majalah, buku, dan surat kabar dapat mendorong anak untuk melakukan tindakan avonturir. ${ }^{22}$

d. Upaya Penanggulangan Kenakalan Anak

Menurut Sarlito Wirawan Sarwono, "untuk mengurangi benturan gejolak remaja dan untuk memberi kesempatan agar remaja dapat mengembangkan dirinya secara lebih optimal, perlu diciptakan kondisi lingkungan terdekat yang setabil mungkin, khususnya lingkungan keluarga. Keadaan keluarga yang ditandai dengan hubungan suami-istri yang harmonis akan lebih menjamin remaja yang bisa melewati masa transisinya dengan mulus daripada jika hubungan suami-istri terganggu. Kondisi di rumah tangga dengan adanya orang tua dan saudara-saudara akan lebih menjamin kesejahteraan jiwa remaja daripada asrama atau lembaga pemasyarakatan anak. Karena itu tindakan pencegahan yang paling utama adalah berusaha menjaga perilaku menyimpang pada remaja keutuhan dan keharmonisan keluarga sebaik-baiknya. Kalau terjadi masalah dengan suami-istri (ada yang meninggal, atau ada perceraian) lebih baik anak dipindahkan ke sanak keluarga lain atau kalau perlu dipindahkan keluarga lain yang tidak ada hubungan darah (misalnya tidak ada sanak-keluarga atau harus kost) perlu dicarikan yang hubungan antar-anggota keluarganya cukup harmonis. Baru sebagai jalan terakhir, kalau tidak ada jalan lain yang lebih baik, bisa dianjurkan asrama atau lembaga pengasuhan anak lainnya seperti Panti Asuhan dan sebagainya, akan tetapi jika dikehendaki perkembangan jiwa anak yang seoptimal mungkin, perlu diusahakan agar keadaan di asrama atau lembaga itu semirip mungkin dengan keadaan dalam keluarga biasa". ${ }^{23}$

\footnotetext{
${ }^{18}$ http://fisip.unpad.ac.id/jurnal/index.php/share/article/view/44, Teori Penyebab Kenakalan Anak, diakses Selasa 2 Juli 2019,pkl 10.00 Wib

19 Ivo Noviana, Kekerasan Seksual Terhadap Anak: Dampak Dan Penanganannya Child Sexual Abuse: Impact And Hendling, Sosio Informa, 2015, Vol. 01, No. 1, hlm. 14

20 Abu Huraerah, Kekerasan terhadap Anak, Bandung, Penerbit Nuansa Cendekia, 2018, hlm. 15

21 Ivo Noviana, Op.Cit.

22 http://jurnal.untag-sby.ac.id/index.php/persona/article/view/27 diakses Selasa 2 Juli 2019,pkl 10.00 WIB

23 https://www.wawasanpendidikan.com/2015/02/upaya-penanggulangan-kenakalan-remaja.html, Penanggulangan Kenakalan Remaja, diakses Selasa 2 Juli 2019.10.30 Wib 
Menurut Zakiah Daradjat, "faktor-faktor terjadinya kenakalan remaja perlu mendapat penanggulangan sedini mungkin dari semua pihak, terutama orang tua, karena orang tua merupakan basis terdepan yang paling dapat mewarnai perilaku anak. ${ }^{24}$ Untuk itu suami atau isteri harus bekerja sama sebagai mitra dalam menanggulangi kenakalan remaja. Selanjutnya pembinaan jiwa agama itu betul-betul dapat membuat kuatnya jiwa si anak untuk menghadapi segala tantangan zaman dan suasana di kemudian hari, hendaknya ia dapat terbina sejak lahir, bahkan sejak dalam kandungan sampai ia mencapai usia dewasa dalam masyarakat. Untuk itu, kiranya pemerintah, pemimpin masyarakat, alim ulama dan para pendidik juga mengadakan usaha peningkatan pendidikan agama bagi keluarga, sekolah dan masyarakat". 25

e. Pengertian Permufakatan Jahat

Roeslan Saleh menyebutkan bahwa permufakatan jahat adalah adanya permufakatan yang disimpulkan dari keterangan-keterangan orang yang bersepakat, persetujuan merupakan suatu tanda yang dapat dilihat mengenai persesuaian kehendak yang merupakan dasar dari adanya pemufakatan. Selanjutnya R. Soesilo menyatakan bahwa pemufakatan jahat adalah pemufakatan untuk berbuat kejahatan, segala pembicaraan atau rundingan untuk mengadakan pemufakatan itu belum masuk pengertian pemufakatan jahat. ${ }^{26}$

f. Permufakatan Jahat Dalam Kejahatan Narkotika

Dalam arti otentik permufakatan jahat dapat dilihat dalam Pasal 88 KUHP yang berbunyi "permufakatan itu terjadi, segera setelah dua orang atau lebih memperoleh kesepakatan untuk melakukan". Permufakatan Jahat (samenspanning) merupakan suatu perencanaan disertai dengan kesepakatan untuk melakukan suatu kejahatan, dapat dikatakan tindak pidana yang disepakati, dipersiapkan atau direncanakan tersebut belum terjadi. Dalam KUHP percobaan dan permufakatan jahat dihukum lebih ringan dari hukuman pokok. ${ }^{27}$

Berbeda dengan Undang-Undang Nomor 35 Tahun 2009 tentang Narkotika yang menghukum permufakatan jahat sama dengan hukuman pokok pada delik selesai (tindak pidana), dikarenakan kejahatan narkotika dianggap sebagai kejahatan serius. Dalam praktiknya, masih banyak aparat penegak hukum menerapkan Pasal 132 ayat (1) UndangUndang Nomor 35 Tahun 2009 tentang Narkotika untuk menjerat tindak pidana selesai yang dilakukan oleh dua orang atau lebih.

Hal ini tidak sesuai dengan pengertian permufakatan jahat yang otentik karena permufakatan jahat yang disebutkan sebagaimana Pasal 1 angka 18 Undang-Undang Nomor 35 Tahun 2009 tentang Narkotika menyebutkan bahwa "permufakatan jahat adalah perbuatan dua orang atau lebih yang bersekongkol atau bersepakat untuk melakukan, melaksanakan, membantu, turut serta melakukan, menyuruh, menganjurkan, memfasilitasi, memberi konsultasi, menjadi anggota suatu organisasi kejahatan narkotika, atau mengorganisasikan suatu tindak pidana narkotika". Pencantuman tanda koma diatas menunjukkan unsur perbuatan permufakatan jahat tersebut bersifat alternatif, sehingga terhadap fakta hukum yang memenuhi salah satu unsurnya dapat dianggap terpenuhinya unsur permufakatan jahat. ${ }^{28}$

24 Asrori, "UPAYA MENANGGULANGI JUVENILE DELENQUENSI MENURUT SARLITO WIRAWAN SARWONO DAN ZAKIAH DARADJAT (TELAAH KOMPARATIF PERSPEKTIF PENDIDIKAN ISLAM)”, Prosiding Seminar Nasional Prodi PAI Universitas Muhammadiyah Purwokerto, 2019.

25 Ibid.

26 Duwi Handoko, Asas-Asas Hukum Pidana dan Hukum Penitensier di Indonesia, Pekanbaru, Hawa dan Ahwa, 2017, hlm. 53

27 http://www.gresnews.com/berita/tips/96184-permufakatan-jahat-dalam-kejahatan-narkotika- $/$ diakses selasa 16 April 2019, pkl. 14.00 wib

28 Ibid, hlm.1 
Untuk melindungi segenap bangsa dan warga Negara dari bahaya laten dengan segenap modus operandi yang semakin canggih, llegislator (DPR) telah merumuskan dan memberlakukan Undang-undang Nomor 35 tahun 2009 tentang Narkotika dan Undangundang Nomor 5 Tahun 1997 tentang Psikotropika. Maka Undang-Undang tersebutlah yang menjadi pedoman aparatur penegak hukum dalam menegakkan hukum dalam kejahatan narkotika. ${ }^{29}$

Permufakatan jahat sebagaimana dimaksud dalam ketentuan Pasal 132 ayat (1) Undang-Undang Nomor 35 Tahun 2009 Tentang Narkotika bersifat ekseptional, yang artinya dianggap sebagai kejahatan pada tindak pidana yang disebutkan dalam UndangUndang Narkotika saja, yakni pasal 111 sampai dengan pasal 126 dan pasal 129 dan kejahatan permufakatan jahatpun dihukum sama dengan kejahatan pasal-pasal 111 sampai dengan pasal 126 dan Pasal 129 tersebut. Unsur-Unsur pasal 132 ayat (1) UndangUndang Nomor 35 Tahun 2009 tentang Narkotika terdiri dari :

a. Percobaan/permufakatan jahat

b. Untuk melakukan tindak pidana narkotika atau prekursor narkotika

c. Sebagaimana dimaksud pasal 111 sampai dengan 126 dan 129 undang-undang narkotika. ${ }^{30}$

Permufakatan jahat (samenspanning) merupakan suatu kejahatan untuk melakukan suatu kejahatan, dapat dikatakan tindak pidana yang disepakati, dipersiapkan atau direncanakan tersebut belum terjadi. ${ }^{31}$ Dalam KUHP, percobaan dan permufakatan jahat hanya dihukum lebih ringan dari hukuman pokok. Namun berbeda dengan UndangUndang Narkotika pada saat ini yang menghukum sama dengan hukuman pokok pada delik selesai dikarenakan Kejahatan Narkotika dipandang telah menjadi kejahatan serius.

Definisi permufakatan jahat mengandung pengertian (deelneming) penyertaan yang dibuat secara alternatif. Sehingga pengertian permufakatan jahat banyak diartikan sebagai deelneming/penyertaan (seperti Pasal 55 KUHP). Dalam praktiknya, masih banyak aparat penegak hukum di Indonesia menerapkan Pasal 132 ayat (1) Undang-Undang Narkotika untuk menjerat pelaku tindak pidana selesai yang dilakukan oleh 2 orang atau lebih. Hal ini tidak sesuai dengan pengertian permufakatan jahat yang otentik karena permufakatan jahat yang didefinisikan Pasal 1 angka 18 Undang-Undang Narkotika dianggap sebagai Lex Speciali Derogat Legi Generali dari Pasal 55 KUHP. ${ }^{32}$

Pasal 132 ayat (1) Undang-Undang Narkotika merupakan pengaturan khusus dari Pasal 169 KUHP dengan melakukan perluasan deelneming-nya (bijzondere deelneming) hal ini dikarenakan kejahatan narkotika semakin meningkat dan membahayakan ketahanan bangsa Indonesia. ${ }^{33}$

Dalam Perkara Nomor : 218/Pid.Sus/2013/Pn.Slmn hakim dalam pertimbangannya memilih dakwaan ketiga yaitu pasal 115 ayat (1) Jo Pasal 132 ayat (1) Undang-Undang Nomor 35 Tahun 2009 tentang Narkotika, Jika diperhatikan sebagaimana pertimbangan hakim dan pengertian dari permufakatan jahat maka terhadap terdakwa bukanlah merupakan suatu permufakatan jahat membawa narkotika golongan I sebagaimana yang diputuskan oleh hakim melainkan tindak pidana selesai karena berdasarkan keterangan para saksi dan keterangan terdakwa menyatakan bahwa ganja tersebut sudah diterima oleh terdakwa, unsur permufakatan jahat yang intinya sepakat untuk melakukan, dalam perkara ini terdakwa sudah melakukan. Maka terhadap terdakwa bukanlah merupakan permufakatan jahat melainkan tindak pidana selesai, dimana terdakwa sudah memiliki,

${ }^{29}$ http://endriprastiono.blogspot.com/2014/01/penerapan-unsur-permufakatan-jahat.html, diakses Senin 15 April 2019, pkl 19.00 Wib

$30 \quad$ Ibid, hlm.1

31 Agung Kurniawan, Tesis: Penerapan Pemufakatan Jahat Dalam Tindak Pidana Narkotika, Banda Aceh, Magister Ilmu Hukum, Universitas Syiah Kuala, 2018,hlm. 41

32 Ibid,

33 Ibid, 
menyimpan, membeli, menerima ganja tersebut yang artinya tindak pidana sudah terjadi, sebagaimana dakwaan kesatu dan kedua dari Penuntut Umum yang dimana dakwaan kesatu adalah Pasal 111 ayat (1) dan yang kedua adalah Pasal 114 ayat (1) UndangUndang Nomor 35 Tahun 2009 tentang Narkotika yang berbunyi :

Pasal 111 ayat (1) "setiap orang tanpa hak atau melawan hukum menanam, memelihara, memiliki,menyimpan mengusai, atau menyediakan narkotika golongan I dalam bentuk tanaman, dipidana dengan pidana penjara paling singkat 4 (empat) tahun dan paling lama 12 (dua belas) tahun dan pidana denda paling sedikit Rp. 800.000.000,00 (delapan ratus juta rupiah) dan paling banyak Rp. 8.000.000.000,00 (delapan miliar rupiah)".

Pasal 114 ayat (1) "Setiap orang yang tanpa hak atau melawan hukum menawarkan untuk dijual, menjual, membeli, menerima, menjadi perantara dalam jual beli, menukar atau menyerahkan narkotika golongan I, dipidana dengan pidana penjara paling singkat 5 (lima) tahun dan paling lama 20 (dua puluh) tahun dan pidana denda paling sedikit Rp. 1.000.000.000,00 (satu miliar rupiah) dan paling banyak Rp. 10.000.000.000,00 (sepuluh miliar rupiah)".

Berdasarkan isi dari Pasal-Pasal tersebut maka jika dilihat dari kesaksian para saksi dan keterangan terdakwa lebih tepatnya terdakwa memiliki atau membeli atau menerima bukan membawa narkotika golongan I. tetapi hakim dalam pertimbangannya menyebutkan bahwa terdakwa dalam membawa narkotika tersebut bukan untuk diperdagangkan atau diperjualbelikan melainkan hanya diminta tolong oleh tanto untuk memesan akan tetapi hakim tidak mempertimbangkan sebagaimana kata membeli, menerima sebagaimana terdapat dalam pasal 114 ayat (1) Undang-Undang narkotika dan hakim menyebutkan bahwa kepemilikan atau pengusaan narkotika harus dilihat maksud dan tujuannya.

Dalam pertimbangan tersebut hakim secara tegas tidak menjelaskan harus dilihat maksud dan tujuan yang seperti apa untuk menentukan seseorang memiliki atau mengusai narkotika.

Putusan Perkara Nomor : 218/Pid.Sus/2013/Pn.Slmn yang menjatuhkan pidana dalam perkara Pemufakatan Jahat Membawa Narkotika Golongan I, terdakwa dijatuhi pidana selama 1 (satu) tahun 6 (enam) bulan yang didakwakan dengan Pasal 115 ayat (1) Jo Pasal 132 ayat (1) Undang-Undang Nomor 35 Tahun 2009 tentang Narkotika Jo UndangUndang Nomor 3 Tahun 1997 tentang Pengadilan Anak, dimana hakim berpendapat bahwa terdakwa memenuhi unsur sebagaimana yang terdapat dalam Pasal 115 ayat (1) Undang-Undang Nomor 35 Tahun 2009 tentang Narkotika menyebutkan bahwa :

"Setiap orang yang tanpa hak atau melawan hukum membawa, mengirim, mengangkut, atau mentransito narkotika golongan I, dipidana dengan pidana penjara paling singkat 4 (empat) tahun dan paling lama 12 (dua belas) tahun dan pidana denda paling sedikit $\mathrm{Rp} 800.000 .000,00$ (delapan ratus juta rupiah) dan paling banyak $\mathrm{Rp}$ 8.000.000.000,00 (delapan miliar rupiah)", selanjutnya Pasal 132 ayat (1) Undang-Undang Narkotika menyebutkan bahwa "Percobaan atau permufakatan jahat untuk melakukan tindak pidana narkotika dan prekursor narkotika sebagaimana dimaksud dalam Pasal 111, 112, 113, 114, 115, 116, 117, 118, 119, 120, 121, 122, 123, 124, 125, 126 dan Pasal 129 pelakunya dipidana dengan pidana yang sama sesuai dengan ketentuan sebagaimana dimaksud dalam Pasal-Pasal tersebut".

Putusan Perkara Nomor : 218/Pid.Sus/2013/Pn.Slmn dalam hal memberatkan disebutkan bahwa terdakwa pernah dihukum. Sebagaimana ketentuan mengenai pemberatan pidana karena pengulangan tindak pidana memiliki tiga faktor yaitu : Faktor lebih dari satu kali melakukan tindak pidana, Faktor telah dijatuhkan pidana terhadap si pembuat oleh negara karena tindak pidana yang pertama, Pidana itu telah dijalankan oleh yang bersangkutan. Sebagaimana faktor-faktor tersebut maka dapat dikatakan bahwa terdakwa memenuhi 2 faktor pemberatan pidana dikarenakan pengulangan tindak pidana 
sebagaimana dikatakan hakim dalam hal yang memberatkan bahwa terdakwa pernah dihukum. ${ }^{34}$

\section{Penjatuhan Sanksi terhadap Terdakwa dalam Perkara Permufakatan Jahat Membawa Prekursor}

\section{a. Teori Pemidanaan}

Istilah Pemidanaan berasal dari inggris yaitu comdemnation theory. Pemidanaan adalah penjatuhan hukuman kepada pelaku yang telah melakukan perbuatan pidana. Perbuatan pidana merupakan: "Perbuatan yang oleh suatu aturan hukum dilarang dan diancam pidana, asal saja dalam pidana itu diingat bahwa larangan ditujukan kepada perbuatan, yaitu suatu keadaan atau kejadian yang ditimbulkan kelakuan orang sedangkan ancaman pidananya ditujukan kepada orang yang menimbulkan kejadian itu". ${ }^{35}$ Tujuan Pemidanaaan:

1) Untuk menakut-nakuti orang agar tidak melakukan kejahatan, baik menakut-nakuti orang banyak (generale preventie), maupun menakut-nakuti orang tertentu yang telah melakukan kejahatan, agar di kemudian hari ia tidak melakukan kejahatan lagi (special preventie).

2) Untuk mendidik atau memperbaiki orang yang sudah menandakan suka melakukan kejahatan, agar menjadi orang yang baik tabiatnya, sehingga bermanfaat bagimasyarakat. Sanksi pidana yang dijatuhkan kepada pelaku kejahatan dapat digolongkan menjadi dua macam yaitu pidana pokok dan pidana tambahan (pasal 10 kitab undang- undang hukum pidana). ${ }^{36}$

Pada umumnya teori-teori pemidanaan terbagi atas tiga golongan besar, yaitu:

1) Teori absolut atau teori retributif

Aliran ini menganggap sebagai dasar dari hukum pidana adalah alam pikiran untuk pembalasan (vergelding atau vergeltung). Teori absolut memandang bahwa pemidanaan merupakan pembalasan atas kesalahan yang telah dilakukan. Jadi berorientasi pada perbuatan dan terletak pada terjadinya kejahatan itu sendiri. Teori retributif mencari pendasaran pemidanaan dengan memandang ke masa lampau, yaitu memusatkan argumennya pada tindakan kejahatan yang telah dilakukan. ${ }^{37}$

2) Teori relatif atau teori tujuan

Teori ini muncul sebagai reaksi keberatan terhadap teori absolut. Menurut teori ini, memidana bukanlah untuk memuaskan tuntutan absolut dari keadilan.Pembalasan itu sendiri tidak mempunyai nilai, tetapi hanya sebagai sarana untuk melindungi kepentingan masyarakat. Oleh karena itu sebagaimana yang telah dikutip dari J. Andaeones, dapat disebut sebagai "teori perlindungan masyarakat" (the theory of social defense). ${ }^{38}$ Teori relatif ini berasal pada tiga tujuan utama pemidanaan yaitu preventif, detterence, dan reformatif. Tujuan preventif (prevention) untuk melindungi masyarakat dengan menempatkan pelaku kejahatan terpisah dari masyarakat. Tujuan menakuti (detterence) untuk menimbulkan rasa takut melakukan kejahatan.Tujuan ini dibedakan tiga bagian, yaitu yang bersifat individual, tujuan bersifat publik dan bersiat jangka panjang. Sedangkan tujuan deterrence yang bersifat publik adalah agar anggota masyarakat lain merasa takut untuk melakukan

34 https://putusan.mahkamahagung.go.id/putusan/46d1bd9588c2a6cb2cb99f2d9e0821c9, Putusan Nomor : 218/Pid.sus/2013/Pn.Slmn, diakses pada 6 November 2018, 11:00 wib, hlm.28

35 R. Abdoel Djamali, Hukum Pengantar Indonesia, Jakarta, Raja Grafindo Persada, 2005, hlm.186

36 Ibid, hlm.187

37 Teguh Prasetyo, Kriminalisasi Dalam Hukum Pidana, Bandung, Nusa Media, 2013, hlm. 87

38 Marlina, Hukum Penitensier, Bandung, Refika Aditama, 2011, hlm. 27-28. 
kejahatan. Dan tujuan deterrence jangka panjang atau long term deterrence adalah agar dapat memelihara sikap masyarakat terhadap pidana. Sedangkan tujuan perubahan (reformation) untuk mengubah sifat jahat si pelaku dengan dilakukannya pembinaan dan pengawasan, sehingga nantinya dapat kembali melanjutkan kebiasaan hidupnya sehari-hari sebagai manusia yang sesuai dengan nilai -nilai yang ada dimasyarakat. ${ }^{39}$

3) Teori gabungan (VerneginsTheorien).

Teori Gabungan yang menitikberatkan pada pandangan bahwa pidana hendaknya didasarkan pada tujuan pembalasan namun juga mengutamakan tata tertib dalam masyarakat, dengan penerapan secara kombinasi yang menitik beratkan pada salah satu unsurnya tanpa menghilangkan unsur lainnya maupun dengan mengutamakan keseimbangan antara kedua unsur yang ada. ${ }^{40}$

b. Dasar pemberatan pidana

Sebagaimana diketahui bahwa pemberatan pidana mempunyai 2 (dua) dasar yaitu Dasar pemberatan pidana umum ialah dasar pemberatan pidana yang berlaku untuk segala macam tindak pidana, baik yang ada di dalam kodifikasi maupun tindak pidana diluar KUHP dan dasar pemberatan pidana khusus dirumuskan dan berlaku pada tindak pidana tertentu saja, dan tidak berlaku untuk tindak pidana yang lain. Undang-Undang mengatur tentang tiga dasar yang menyebabkan pemberatan pidana umum, ialah: ${ }^{41}$

1) Karena jabatan

Dasar pemberatan karena jabatan ditentukan dalam Pasal 52 KUHP yang rumusan lengkapnya adalah: "Bilamana seorang pejabat karena melakukan tindak pidana melanggar suatu kewajiban khusus dari jabatannya, atau pada waktu melakukan tindak pidana memakai kekuasaan, kesempatan dan sarana yang diberikan kepadanya karena jabatannya, pidananya ditambah sepertiga". Dasar pemberat pidana dalam Pasal 52 ini adalah terletak pada keadan jabatan dari kualitas si pembuat (pejabat atau pegawai negeri) mengenai 4 hal, yaitu dalam melakukan tindak pidana dengan: Melanggar suatu kewajiban khusus dari jabatannya, Memakai kekuasaan jabatannya, Menggunakan kesempatan karena jabatannya, Menggunakan sarana yang diberikan karena jabatannya.

Subjek hukum yang diperberat pidananya dengan dapat ditambah sepertiga, adalah bagi seorang pejabat atau pegawai negeri yang melakukan tindak pidana dengan melanggar dan atau menggunakan 4 keadaan tersebut di atas. ${ }^{42}$

2) Karena menggunakan sarana bendera

Dasar Pemberatan Pidana dengan Menggunakan Sarana Bendera Kebangsaan Melakukan suatu tindak pidana dengan menggunakan sarana bendera kebangsaan dirumuskan dalam Pasal 52 (a) KUHP disebutkan secara tegas penggunaan bendera kebangsaan itu adalah waktu melakukan kejahatan, maka tidak berlaku pada pelanggaran, ini berlaku pada kejahatan manapun, termasuk kejahatan menurut perundang - undangan diluar KUHP. ${ }^{43}$

39 Teguh Prasetyo, Op.Cit, hlm. 92-93.

40 Inge Meylinda Wiyana, Tesis: EFEKTIFITAS PELAKSANAAN PIDANA PENJARA BAGI NARAPIDANA NARKOTIKA YANG MELAKUKAN PENGULANGAN (RESIDIVIS) DITINJAU DARI TUJUAN PEMIDANAAN (Studi di Lembaga Pemasyarakatan Kelas II B Mojokerto), Malang, Fakultas Hukum, Universitas Muhammadiyah Malang, 2018, hlm. 28.

41 Adami Chazawi, Pelajaran Hukum Pidana; Penafsiran Hukum Pidana, Dasar Pemidanaan, Pemberatan \& Peringanan, Kejahatan Aduan, Perbarengan \& Ajaran Kausalitas, Jakarta, Raja Grafindo Persada, 2002, hlm. 73.

$42 \quad$ Ibid, hlm.73

43 Ibid, 
3) Karena pengulangan tindak pidana

Dasar Pemberatan Pidana karena Pengulangan Ada 2 (dua) arti pengulangan yang satu menurut masyarakat dan yang satu menurut hukum pidana. Menurut masyarakat (sosial), masyarakat menganggap bahwa setiap orang yang setelah dipidana yang kemudian melakukan tindak pidana lagi, disini ada pengulanngan tanpa memperhatikan syarat-syarat lainnya. Sedangkan pengulangan menurut hukum pidana, yang merupakan dasar pemberat pidana ini tidaklah cukup hanya melihat berulangnya melakukan tindak pidana tetapi juga dikaitkan pada syaratsyarat tertentu yang ditetapkan oleh undang-undang. ${ }^{4}{ }^{4}$

Adapun dasar pemberatan pidana pada pengulangan ini terletak pada 3 faktor yaitu:

1) Faktor lebih dari satu kali melakukan tindak pidana.

2) Faktor telah dijatuhkan pidana terhadap si pembuat oleh negara karena tindak pidana yang pertama.

3) Pidana itu telah dijalankan oleh yang bersangkutan.

Selain dasar pemberatan pidana umum, undang-undang juga menyebutkan dasar alasan pemberatan pidana khusus. Disebut dasar pemberatan pidana khusus, karena hanya berlaku pada tindak pidana tertentu yang dicantumkan alasan pemberatan itu saja, dan tidak berlaku pada tindak pidana lain. ${ }^{45}$

\section{Simpulan dan Saran}

\section{Simpulan}

Berdasarkan penulisan studi kasus dari Putusan Pengadilan Negeri Sleman yang di uraikan mengenai pemidanaan terhadap anak pembawa prekursor narkotika di Pengadilan Negeri Sleman dapat diperoleh kesimpulan sebagai berikut :

a. Sebagaimana diketahui berdasarkan Putusan Perkara Nomor: 218/Pid.Sus/2013/Pn.Slmn terdakwa dikatakan melakukan pemufakatan jahat membawa prekursor narkotika akan tetapi permufakatan jahat yang disebutkan oleh hakim tidak jelas karena hakim secara tegas tidak menyebutkan perbuatan yang mana yang merupakan permufakatan jahat sehingga masih perlu dipertimbangkan.

b. Penjatuhan sanksi terhadap terdakwa sudah tepat karena hakim tidak menganggap perbuatan terdahulu terdakwa adalah residive karena ketentuan dalam dalam UndangUndang Narkotika menganut residive khusus, karena dahulu terdakwa dipidana bukan karena perbuatan narkotika sehingga dalam pertimbangannya hakim menyebutkan terdakwa baru pertama kali melakukan tindak pidana narkotika.

\section{Saran}

Saran yang akan saya tuangkan dalam studi kasus ini tentang pemidanaan terhadap anak pembawa prekursor narkotika di Pengadilan Negeri Sleman sebagai berikut :

a. Kepada Majelis Hakim agar lebih teliti dalam memilih dakwaan yang diajukan oleh Jaksa Penuntut Umum, dan dalam pertimbangannya harus lebih memperjelas tentang bentuk permufakatan jahat.

b. Kepada Penuntut Umum agar lebih teliti dalam menentukan dakwaan.

\section{DAFTAR PUSTAKA}

\section{Buku}

Abu Huraerah, 2018, Kekerasan terhadap Anak, Bandung: Penerbit Nuansa Cendekia.

44 Ibid, hlm.74

45 Ibid, hlm.88 
Adami Chazawi, 2002, Pelajaran Hukum Pidana; Penafsiran Hukum Pidana, Dasar Pemidanaan, Pemberatan \& Peringanan, Kejahatan Aduan, Perbarengan \& Ajaran Kausalitas, Jakarta, Raja Grafindo Persada.

Aziz Syamsuddin, 2014, Tindak Pidana Khusus, Jakarta, Sinar Grafika.

Duwi Handoko, 2017, Asas-Asas Hukum Pidana dan Hukum Penitensier di Indonesia, Pekanbaru, Hawa dan Ahwa.

Marlina, 2011, Hukum Penitensier, Bandung, Refika Aditama.

Muhammad Taufik Makarao dkk, 2013, Hukum Perlindungan Anak dan Perempuan dalam Kekerasan Rumah Tangga, Jakarta, Rineka Cipta.

Mukti Fajar \& Yulianto Achmad, 2015, Dualisme Penelitian Hukum Normatif \& Empiris, Yogyakarta, Pustaka Pelajar.

Nandang Sambas, 2010, Pembaruan Sistem Pemidanan Anak di Indonesia, Yogyakarta, Graha Ilmu.

Peter mahmud marzuki, 2013, Penelitian hukum, Jakarta, kencana prenada media group.

R. Abdoel Djamali, 2005, Hukum Pengantar Indonesia, Jakarta,Raja Grafindo Persada.

Teguh Prasetyo, 2013, Kriminalisasi Dalam Hukum Pidana, Bandung, Nusa Media.

Jurnal

Anton Sudanto, 2017, PENERAPAN HUKUM PIDANA NARKOTIKA DI INDONESIA, ADIL: Jurnal Hukum, Vol. 7 No.1.

Ayu A. A Hamzah, 2014, PEMIDANAAN TERHADAP PENYALAHGUNAAN PREKURSOR DI KALANGAN KORPORASI, Jurnal Lex Crimen, Vol. 3 No. 2.

B.K Wijaya, Dasar Pertimbangan Hakim Dalam Menjatuhkan Putusan Kasus Anak Yang Berkonflik Dengan Hukum, Diponegoro Law Journal Vol.V/No.4/2016

Didik Endro Purwoleksono, Penanganan Perkara Pidana Anak yang Tersangka/Terdakwanya Anak-Anak, Jurnal Ilmu Hukum, Universitas Airlangga, Vol.19/No.III/2004

Dyana C. Jatmika, Nandang Mulyana, dan Santoso Tri Raharjo, Residivis Anak Sebagai Akibat Dari Rendahnya Kesiapan Anak Didik Lembaga Pemasyarakatan Dalam Menghadapi Proses Integrasi ke Dalam Masyarakat, Jurnal Hukum Unpad, Vol.V/No.I/2015

Frezcilia Dewi Daleda, Kajian Yuridis Terhadap Perbuatan Yang Direncanakan Terlebih Dahulu Sebagai Unsur Delik Yang Memberatkan, Lex Crimen, Vol.VI/No.VI/2017

Ida Nor Shanty, Suyahmo dan Slamet Sumarto, 2015, FAKTOR PENYEBAB KENAKALAN REMAJA PADA ANAK KELUARGA BURUH PABRIK ROKOK DJARUM DI KUDUS, Unnes Civic Education Journal, Vol.1 No. 2

Immanuel Christophel Liwe, Kewenangan Hakim dalam Memeriksa dan Memutus Perkara Pidana yang Diajukan ke Pengadilan, Lex Crimen, Vol.II/No.7/2013

Ivo Noviana, 2015, KEKERASAN SEKSUAL TERHADAP ANAK: DAMPAK DAN PENANGANANNYA CHILD SEXUAL ABUSE: IMPACT AND HENDLING, Sosio Informa, Vol. 01, No. 1.

Ngawiardi, "Kajian Kriminologi Terhadap Kejahatan Pencabulan Anak Di bawah Umur di Parigi Moutong”, Jurnal Untad, Vol.IV/No.4/2016

R.Atang Ranoemihardja, Kajian Yuridis Terhadap Perbuatan Yang Direncanakan Terlebih Dahulu Sebagai Unsur Delik Yang Memberatkan, Lex Crimen, Vol.VI/No.VI/2017

R.B.Sularto, Budhi Wisaksono, Agung Pambudi, Pengaruh Sistem Pembinaan di Lembaga Pemasyarakatan sebagai Bentuk Pertanggungjawaban Pidana dengan Peningkatan Jumlah Narapidana Residivis, Diponegoro Law Journal, Vol.V/No.III/2016 
Tengku M.D Rizal, Tanggung Jawab Profesi Hakim Sebagai Penyelenggara Kekuasaan Kehakiman di Indonesia, Jurnal Ilmu Hukum, Universitas Indonesia Vo.I/ No.I,/2012

Artikel

Asrori, 2019, "UPAYA MENANGGULANGI JUVENILE DELENQUENSI MENURUT SARLITO WIRAWAN SARWONO DAN ZAKIAH DARADJAT (TELAAH KOMPARATIF PERSPEKTIF PENDIDIKAN ISLAM)", Prosiding Seminar Nasional Prodi PAI Universitas Muhammadiyah Purwokerto.

\section{Skripsi/Tesis}

Agung Kurniawan, 2018, PENERAPAN PEMUFAKATAN JAHAT DALAM TINDAK PIDANA NARKOTIKA, Tesis, Magister Ilmu Hukum, Universitas Syiah Kuala, Banda Aceh.

Titik Hastary, 2013, Perlindungan Hukum Terhadap Anak Yang Melakukan Tindak Pidana (Studi Di Pengadilan Negeri Sukoharjo), Skripsi, Fakultas Hukum, Universitas Muhammadiyah Surakarta, Surakarta.

Inge Meylinda Wiyana, 2018, EFEKTIFITAS PELAKSANAAN PIDANA PENJARA BAGI NARAPIDANA NARKOTIKA YANG MELAKUKAN PENGULANGAN (RESIDIVIS) DITINJAU DARI TUJUAN PEMIDANAAN (Studi di Lembaga Pemasyarakatan Kelas II B Mojokerto), Tesis, Fakultas Hukum, Universitas Muhammadiyah Malang, Malang.

\section{Internet}

https://www.neliti.com/id/universitas-tadulako?per_page=50\&page=10, Ngawiardi, "Kajian Kriminologi Terhadap Kejahatan Pencabulan Anak Di bawah Umur di Parigi Moutong", diakses Selasa 7 Mei 2019

https://putusan.mahkamahagung.go.id/putusan/46d1bd9588c2a6cb2cb99f2d9e0821c9, Putusan Nomor : 218/Pid.sus/2013/Pn.Slmn, diakses pada 6 November 2018, 11:00 wib, hlm.23

https://putusan.mahkamahagung.go.id/putusan/cf17ede036c7f818b1cfd928c1b3a9a2, diakses Senin 1 Juli 2019, $21.00 \mathrm{Wib}$

https://jurnal.usu.ac.id/index.php/impk/article/view/1483/diakses Senin 1 Juli 2019, 20.30 Wib

http://fisip.unpad.ac.id/jurnal/index.php/share/article/view/44, Teori Penyebab Kenakalan Anak, diakses Selasa 2 Juli 2019,pkl 10.00 Wib

http://jurnal.untag-sby.ac.id/index.php/persona/article/view/27, diakses Selasa 2 Juli 2019,pkl 10.00 Wib

https://www.wawasanpendidikan.com/2015/02/upaya-penanggulangan-kenakalan-remaja.html, Upaya Penanggulangan Kenakalan Remaja, diakses Selasa 2 Juli 2019.10.30 Wib

http://www.gresnews.com/berita/tips/96184-permufakatan-jahat-dalam-kejahatan-narkotika-/, diakses selasa 16 April 2019, pkl. 14.00 wib

http://endriprastiono.blogspot.com/2014/01/penerapan-unsur-permufakatan-jahat.html, diakses Senin 15 April 2019, pkl 19.00 Wib 